\title{
Potensi Jamur Perakaran sebagai Agens Pengendalian Hayati Penyakit Moler (Fusarium oxysporum f.sp. Cepae) pada Bawang Merah
}

\section{Potential of Root-Colonizing Fungi as Biocontrol Agent of Moler Desease (Fusarium oxysporum f. sp. Cepae) on Shallot}

\author{
Andhika Wahyu Nugroho ${ }^{1)}$, Hadiwiyono ${ }^{2)}$, Sudadi ${ }^{2)}$
}

\begin{abstract}
Desease that often occurs on the shallot is moler caused by Fusarium oxysporum f. sp. cepae (FOCe). This research was conducted to studied the potential of root-colonizing fungi to suppres moler disease on shallot. The researchs were divided into two steps that were laboratory test and screen house test used Completely Randomized Design (CRD). The treatments in screen house test were the combination of four fungi that had best capability to inhibit growth of FOCe. Each treatment was repeated three times. The result showed that rootcolonizing fungi could reduce the moler disease but haven't affect significantly growth component of shallot. Lowest disease intensity was $20 \%$ on the combination of AJ01, AJ12, AJ17, AJ18. Root-colonizing fungi have potention to decrease Moler disease.
\end{abstract}

Keywords : shallot, moler disease, FOCe, root-colonizing fungi

\section{PENDAHULUAN}

Setiap rumah tangga pasti membutuhkan bawang merah untuk bumbu masak karena hampir semua masakan membutuhkan komoditas ini. Bawang merah mempunyai banyak manfaat, disamping sebagai bumbu masakan juga dapat digunakan untuk obat. Umumnya tanaman bawang merah ditanam di musim kemarau. Namun di beberapa sentra produksi bawang merah, penanaman bawang merah tidak mengenal musim dan dapat ditanam kapan saja dengan sistem budidaya yang intensif. Masalah utama usaha tani bawang merah bila penanaman di luar musim adalah tingginya resiko kegagalan panen. Budidaya bawang merah terdapat banyak kendala, serangan hama penyakit merupakan salah satu kendala yang cukup penting yang harus ditangani.

Fusarium oxysporum f.sp. cepae Schlechtend.:Fr. (Hans HN), Snyder WC, Hans HN. merupakan patogen yang menyebabkan busuk pangkal pada bawang merah (Fourie et al. 2009). Patogen ini menyerang akar dan umbi, gejala yang muncul berupa pembusukan akar, perubahan warna hingga nekrosis. Jamur FOCe dapat menyebabkan penyakit Busuk Pangkal atau di Indonesia lebih dikenal dengan penyakit Moler. Pengendalian menggunakan fungisida tidak efektif terhadap serangan FOCe (Sintyayehu 2010). Pengendalian biologi menggunakan agens hayati jamur dan bakteri antagonis telah disarankan sebagai metode pengendalian busuk pangkal (Cramer 2000).

Israel dan Lodha (2005) melaporkan bahwa pemberian satu jenis atau lebih agens hayati akan lebih baik dalam menurunkan serangan FOCe. Tanah

\footnotetext{
1) Undergraduate Student of Study Program of Agrotechnology, Faculty of Agriculture University of Sebelas Maret (UNS) in Surakarta.

2) Lecturer of Study Program of Agrotechnology, Faculty of Agriculture University of Sebelas Maret (UNS) in Surakarta.
}

Contact Author: hadi_hpt@yahoo.com perakaran sumber yang baik untuk isolasi agens hayati (Huang et al. 2013). Toyota et al. (1994) melaporkan bahwa mikrob pengkoloni akar bertanggungjawab dalam penekanan patogen. Mikrob antagonis perakaran adalah agens hayati yang ideal karena daerah perakaran merupakan pertahanan utama pada akar melawan infeksi dari patogen (Murali 2012). Tujuan dari pelaksanaan penelitian ini adalah mengkaji potensi jamur perakaran bawang merah dalam menekan moler pada bawang merah.

\section{METODE PENELITIAN}

\section{Percobaan Laboratorium}

Isolasi Fusarium oxysporum f. sp. cepae (FOCe)

Isolasi Fusarium oxysporum f. sp. cepae dilaksanakan pada bulan Juni-Agustus 2013 dengan metode direct plating. Bagian tanaman yang sakit dipotong $0,5 \mathrm{~cm}$ ditanam dalam media PDA dan diberi anti-bakteri berupa asam laktat. FOCe menunjukkan koloni yang berwarna merah jambu.

Pengambilan sampel dan isolasi jamur perakaran Bawang merah

Pengambilan sampel ditentukan melalui purposive sampling dengan sampel berupa tanaman bawang merah yang berasal dari Ngargoyoso, Bantul, Palur dan Tawangmangu. Pengambilan sampel dan isolasi jamur perakaran bawang merah dilaksanakan pada bulan Agustus-November 2013. Isolasi dilakukan dengan metode Direct plating. Akar tanaman bawang merah ditanam pada media PDA dalam cawan petri dan diinkubasi selama 7 hari. Jamur perakaran yang tumbuh kemudian disubkultur sehingga tumbuh menjadi biakan murni.

Uji penghambatan FOCe dengan jamur perakaran

Uji penghambatan dilakukan dengan metode dual culture dilaksanakan pada bulan Desember 2013 Februari 2014. Koloni jamur perakaran bawang merah 
dipotong dengan diameter $5 \mathrm{~mm}$ kemudian dikulturkan pada PDA dengan jarak $3 \mathrm{~cm}$ dari tepian cawan Petri pada sisi yang lain FOCe. Persentase hambatan dihitung pada hari ke -7 dengan rumus:

Persentase hambatan $=\frac{r 1-r 2}{r 2} \times 100 \%$

dimana $\mathrm{r} 1$ = jari-jari $F O C e$ menjauhi jamur perakaran dan r2 : jari-jari FOCe mendekati jamur perakaran. Data pengamatan dianalisis ragam dengan uji $F$ taraf $5 \%$.

\section{Percobaan Rumah Kasa}

Percobaan rumah kasa dilaksanakan pada bulan Juni 2014 - Juli 2014. Isolat jamur perakaran yang mampu menghambat pertumbuhan FOCe dan FOCe dibiakkan dalam $400 \mathrm{~mL}$ media cair. Setelah jamur perakaran mencapai kepadatan spora $10^{7}$ kemudian dicampur menjadi $10 \mathrm{~mL}$ suspensi sesuai kombinasi perlakuan jamur perakaran yang telah dibuat. Suspensi diaplikasikan dengan cara disiramkan pada saat penanaman benih bawang merah.

Umbi bawang merah ditanam pada media tanah dalam polibag yang telah disterilisasi dengan cara dikukus selama 6 jam. Setiap polibag terdapat tiga bibit bawang merah yang merupakan unit dalam satu ulangan perlakuan. Pengamatan jumlah daun, intensitas penyakit dan tinggi tanaman dilakukan setiap tiga hari sekali dimulai pada 3 HST hingga 36 HST. Laju infeksi, LBKPP, waktu muncul gejala dan berat basah diamati pada akhir pengamatan.

Intensitas penyakit per unit perlakuan dihitung dengan rumus sebagai berikut:

$I P=\frac{\sum(n x v)}{N x Z} 100 \%$

dengan $I P=$ Intensitas penyakit; $n=$ Jumlah tanaman yang diamati menunjukan skor tertentu; $v=$ Skor bawang merah $(0=$ Tanpa gejala, $1=$ Sebagian daun menguning tetapi belum kering, 2 =Sebagian daun kering tetapi belum layu, $3=$ Tanaman layu tetapi belum busuk, 4 = Busuk umbi, 5 = Tanaman mati); $N$ $=$ Nilai skor tertinggi $Z$ = Jumlah seluruh tanaman.

Laju infeksi diamati setiap 3 hari per unit perlakuan dengan rumus sebagai berikut:

$r=\frac{\log X t-\log X o}{t \cdot \log e}$

dengan $r=$ Laju infeksi; $X t=$ Intensitas penyakit waktu $\mathrm{t} ; X_{O}=$ Intensitas penyakit awal; $e=$ Tetapan $(2,7182818) ; t=$ Waktu pengamatan.

LBKPP diamati setiap 3 hari per unit perlakuan kemudian dihitung dengan rumus sebagai berikut:

$L B K P P=\sum_{i: 1}^{n} \frac{X_{(i+1)}+X 1}{2}\left(t_{(i+1)}-t i\right)$

dengan $\angle B K P P=$ Luas bawah kurva perkembangan penyakit; $X i=$ Intensitas penyakit minggu ke-l; $t i=$ Waktu pengamatan ke-l; $n=$ Pengamatan saat terminal penyakit. Percobaan rumah kasa menggunakan Rancangan Acak Lengkap dengan perlakuan kombinasi 4 jamur hasil percobaan laboratorium yang paling kuat menghambat $F O C e$ yaitu AJ01, AJ12, AJ17 dan AJ18.

\section{HASIL DAN PEMBAHASAN}

\section{Percobaan Laboratorium}

Interaksi dasar dalam metode dual culture adalah mekanisme penyerangan dan pertahanan oleh masing-masing organisme. Gambar 1 menunjukkan bahwa terdapat 4 isolat jamur dengan penghambatan lebih dari $45 \%$. Isolat inilah yang digunakan untuk percobaan rumah kasa, antara lain AJ01, AJ12, AJ17, dan AJ18.

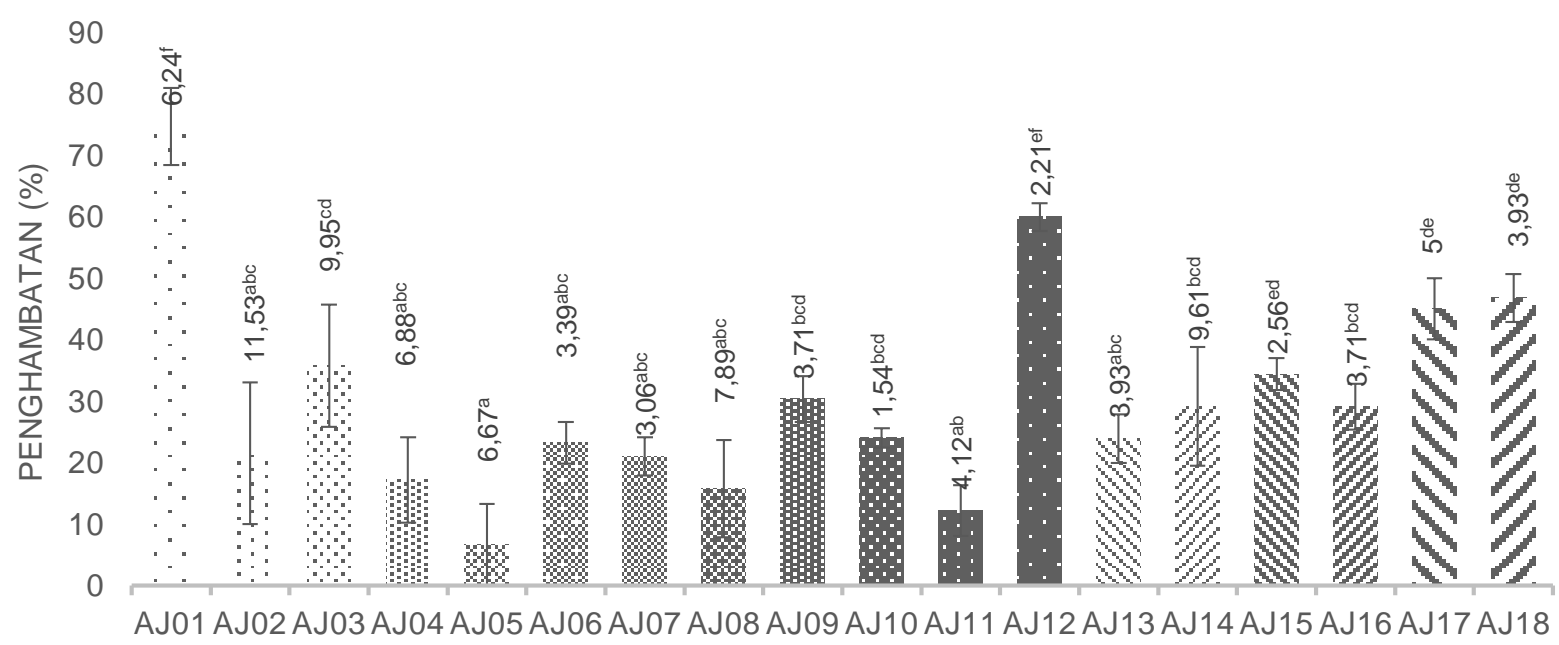

Keterangan: Angka yang diikuti huruf yang berbeda menunjukkan berbeda nyata dengan DMRT $5 \%$. Bar menunjukan standar eror.

Gambar 1. Histogram potensi penghambatan jamur terduga antagonis terhadap pertumbuhan koloni FOCe 
Pengujian antagonis menunjukkan bahwa semua isolat yang diuji memiliki kemampuan untuk menekan pertumbuhan koloni FOCe. Perbedaan daya hambat oleh antagonis ditentukan oleh fisiologi dari antagonis tersebut. Mikrob mempunyai berbagai tipe antagonis terhadap patogen. Tipe tersebut meliputi, mekanisme antagonis secara langsung, antagonis secara tidak langsung dan antagonis campuran antara langsung dan tidak langsung. Tipe antagonis secara langsung terjadi melalui mekanisme hiperparasitisme yaitu dengan menekan dan mematikan patogen secara langsung. Tipe antagonis secara tidak langsung terjadi melalui mekanisme kompetisi dan induksi ketahanan tanaman. Tipe antagonis campuran dapat terjadi melalui produksi antibiotik, enzim litik, dan pengaruh sifat tanah (Pal 2006).

\section{Percobaan Rumah Kasa}

Pengamatan intensitas penyakit (Tabel 1) menunjukkan bahwa bawang merah yang diberi perlakuan kombinasi AJ01, AJ012, AJ017 dan AJ018 memiliki intensitas penyakit moler paling rendah yaitu $20 \%$ dan secara statistik tidak berbeda nyata dengan tanaman kontrol (-). Song (2014) mengatakan bahwa serangan penyakit akan meningkat jika jumlah populasi patogen tinggi. Secara umum aplikasi agens hayati secara individual tidak selalu konsisten melawan patogen (Suárez-Estrella 2013). Pemberian lebih dari satu jenis antagonis membuat FOCe terisolasi dari lingkungan dan sulit menginfeksi tanaman sehingga menurunkan intensitas penyakit. Soesanto et al. (2009) menambahkan bahwa adanya penghambatan oleh suatu agens antagonis dapat menyebabkan jamur patogen tumbuhan hanya mampu menyerang terbatas pada bagian tanaman tertentu sehingga keparahan penyakit cukup rendah. Penggunaan agens hayati dalam pengendalian serangan Fusarium oxysporum mampu mengurangi pertumbuhan FOCe dalam percobaan pot (Gangadara et al. 2011).

Tabel 1. Potensi jamur antagonis terpilih terhadap serangan FOCe dan pertumbuhan tanaman

\begin{tabular}{|c|c|c|c|c|c|c|c|c|c|c|c|c|}
\hline \multirow{2}{*}{$\begin{array}{l}\text { Isolat } \\
\text { Kontrol - (Tanpa Inokulasi) }\end{array}$} & \multicolumn{2}{|c|}{$\begin{array}{l}\text { Intensitas } \\
\text { Penyakit } \\
(\%)\end{array}$} & \multicolumn{2}{|c|}{$\begin{array}{l}\text { Laju Infeksi } \\
\text { (Unit/hari) }\end{array}$} & \multicolumn{2}{|l|}{ LBKPP } & \multicolumn{2}{|c|}{$\begin{array}{c}\text { Tinggi } \\
\text { Tanaman }(\mathrm{cm})\end{array}$} & \multicolumn{2}{|c|}{$\begin{array}{l}\text { Jumlah } \\
\text { Daun }\end{array}$} & \multicolumn{2}{|c|}{$\begin{array}{c}\text { Berat } \\
\text { Segar (gr) }\end{array}$} \\
\hline & 11,11 & a & 0,00 & a & 3,00 & a & 20,19 & $a b$ & 3,56 & $\begin{array}{l}a \\
b\end{array}$ & 5,83 & $b c$ \\
\hline Kontrol + (Inokulasi Patogen) & 84,44 & ef & 0,26 & $b$ & 217,44 & $\begin{array}{l}a \\
b\end{array}$ & 28,36 & $a b$ & 4,22 & $\begin{array}{l}a \\
b\end{array}$ & 3,27 & $a b c$ \\
\hline AJ01 & 86,6 & $f$ & 0,17 & $b$ & 135,22 & $\begin{array}{l}a \\
b\end{array}$ & 23,84 & $a b$ & 4,00 & $\begin{array}{l}a \\
b\end{array}$ & 2,76 & $a b c$ \\
\hline AJ12 & 86,67 & $f$ & 0,25 & $b$ & 179,67 & $\begin{array}{l}a \\
b\end{array}$ & 30,50 & $a b$ & 4,22 & $\begin{array}{l}a \\
b\end{array}$ & 2,39 & $a b c$ \\
\hline AJ17 & 77,78 & def & 0,21 & $b$ & 217,44 & $\begin{array}{l}\mathrm{a} \\
\mathrm{b}\end{array}$ & 27,41 & $a b$ & 4,22 & $\begin{array}{l}a \\
b\end{array}$ & 2,98 & $a b c$ \\
\hline AJ18 & 80,00 & ef & 0,26 & $b$ & 208,56 & $\begin{array}{l}a \\
b\end{array}$ & 26,10 & $a b$ & 3,67 & $\begin{array}{l}a \\
b\end{array}$ & 1,84 & $a b c$ \\
\hline AJ01, AJ12 & 84,44 & ef & 0,26 & $b$ & 241,89 & $b$ & 31,36 & $b$ & 4,00 & $\mathrm{~b}$ & 1,40 & $a b$ \\
\hline AJ01, AJ17 & 48,89 & abcdef & 0,28 & $\mathrm{~b}$ & 267,44 & $\mathrm{~b}$ & 22,18 & $a b$ & 3,00 & $\begin{array}{l}a \\
b\end{array}$ & 1,58 & $a b c$ \\
\hline AJ01, AJ18 & 55,56 & bcdef & 0,28 & $b$ & 235,22 & $b$ & 24,04 & $a b$ & 4,33 & $\begin{array}{l}a \\
b\end{array}$ & 1,68 & $a b c$ \\
\hline AJ12, AJ17 & 75,5 & def & 0,19 & $b$ & 101,89 & $\begin{array}{l}a \\
b\end{array}$ & 25,04 & $a b$ & 3,67 & $\begin{array}{l}a \\
b\end{array}$ & 3,27 & $a b c$ \\
\hline AJ12, AJ18 & 46,67 & bcde & 0,24 & $b$ & 194,11 & $\begin{array}{l}a \\
b\end{array}$ & 24,28 & $a b$ & 3,78 & $\begin{array}{l}a \\
b\end{array}$ & 5,54 & $b c$ \\
\hline AJ17, AJ18 & 33,33 & $a b c$ & 0,36 & $b$ & 209,67 & $\begin{array}{l}a \\
b\end{array}$ & 28,94 & $a b$ & 5,00 & $\begin{array}{l}a \\
b\end{array}$ & 6,00 & c \\
\hline AJ01, AJ12, AJ17 & 48,8 & abcdef & 0,28 & $b$ & 243,00 & $b$ & 27,14 & $a b$ & 3,56 & $\begin{array}{l}a \\
b\end{array}$ & 3,41 & $a b c$ \\
\hline AJ01, AJ12, AJ18 & 40,00 & abcd & 0,24 & $b$ & 174,11 & $\begin{array}{l}a \\
b\end{array}$ & 24,92 & $a b$ & 3,56 & $\begin{array}{l}a \\
b\end{array}$ & 2,89 & $a b c$ \\
\hline AJ01, AJ17, AJ18 & 24,44 & $a b c$ & 0,23 & $b$ & 139,67 & $\begin{array}{l}a \\
b\end{array}$ & 19,63 & $a b$ & 4,00 & $\begin{array}{l}a \\
b\end{array}$ & 3,58 & $a b c$ \\
\hline AJ12, AJ17, AJ18 & 60,00 & cdef & 0,31 & $b$ & 268,56 & $b$ & 23,91 & $a b$ & 3,67 & $\begin{array}{l}a \\
b\end{array}$ & 2,63 & $a b c$ \\
\hline AJ01, AJ12, AJ17, AJ18 & 20,00 & $a b$ & 0,18 & $b$ & 56,33 & $\begin{array}{l}a \\
b\end{array}$ & 17,92 & a & 3,22 & a & 1,0 & a \\
\hline
\end{tabular}

Keterangan: Angka-angka pada kolom yang sama dan diikuti huruf yang sama menunjukkan tidak berbeda nyata pada uji DMRT taraf $5 \%$.

Angka laju infeksi yang kecil berarti jamur perakaran mampu menghambat pertumbuhan FOCe. Pemberian jamur perakaran pada tanaman bawang merah membuat kondisi lingkungan mikro didalam tanah tidak sesuai untuk pertumbuhan FOCe sehingga kemampuanya dalam melakukan infeksi kedalam tanaman menurun. Laju infeksi sangat berkaitan dengan kondisi lingkungan, saat kondisi lingkungan tidak sesuai dengan pertumbuhan patogen, maka patogen tidak dapat tumbuh secara optimal. Jamur perakaran dapat mengeluarkan metabolit sekunder yang bersifat toksik bagi FOCe, beberapa jamur perakaran memiliki sifat sebagai mikoparasit yang dapat menyebabkan lisis pada hifa 
FOCe, persaingaan dalam memperebutkan nutrisi juga dapat menjadi penyebab penurunan laju infeksi FOCe akibat pemberian jamur perakaran yang memiliki kemampuan sebagai agens pengendalian hayati. Selaras dengan intensitas penyakit pemberian kombinasi agens hayati yang lebih banyak memberikan hasil yang lebih baik.

Laju infeksi sangat dipengaruhi oleh kondisi lingkungan seperti yang diungkapkan oleh Agrios (2005) bahwa Kondisi lingkungan sangat berpengaruh terhadap kerentanan tanaman terhadap patogen, kemampuan patogenisitas patogen dan kondisi fisiologi tanaman. Heil dan Bostock (2002) juga menyatakan bahwa sistem pertahanan tanaman sangat bergantung kepada interaksi inang, patogen, dan lingkungan. Interaksi antara tanaman dengan patogen menghasilkan reaksi kesesuaian (infeksi) atau ketidaksesuaian (ketahanan). Penekanan penyakit oleh agens hayati terdapat pada semua pengamatan, tetapi nilai penekanan bervariasi tergantung pada kesesuaian agens hayati terhadap lingkungan (Shisido et al. 2005),

Hasil yang diperoleh dari perhitungan AUDPC selaras dengan nilai yang diperoleh dari hasil pengamatan insidens penyakit. Besarnya potensi patogen FOCe dari data tersebut menunjukkan FOCe sebagai patogen yang penting pada bawang merah. Beberapa perlakuan kombinasi terlihat tidak efektif dalam menekan FOCe, kompatibilitas antar antagonis serta kemampuanya dalam beradaptasi dengan lingkungan yang berbeda sehingga kemampuanya dalam mengkoloni akar menjadi berkurang merupakan salah satu penyebab ketidak efektifan dari kombinasi isolat tersebut. Susanna (2006) menambahkan bahwa keefektifan agens antagonis sangat dipengaruhi oleh senyawa metabolit yang mampu menekan infeksi patogen dan kemampuannya dalam mengkolonisasi perakaran.

Berdasarkan uji in planta pemberian isolat terpilih antagonis tidak mampu meningkatkan komponen pertumbuhan tanaman seperti tinggi tanaman, jumlah daun, dan berat segar tanaman. Mikrob mampu mempengaruhi pertumbuhan tanaman jika mikrob tersebut mampu menghasilkan senyawaa metabolit yang mampu menginduksi tanaman. Isolat-isolat terpilih antagonis tidak mampu meningkatkan komponen pertumbuhan tanaman karena tidak menghasilkan senyawa metabolit khusus. FOCe adalah jamur patogen yang mampu memproduksi enzim exo-polygalacturonase (exo-PG) dan endopectin-trans-eliminase (endo-PTE). Rendahnya berat segar tanaman diduga karena pengaruh senyawa toksin yang dihasilkan oleh FOCe. Toksintoksin tersebut akan mengubah permeabilitas membran plasma dari sel tanaman inang sehingga tanaman lebih cepat kehilangan air (Sastrahidayat 1990).

\section{KESIMPULAN DAN SARAN}

Jamur perakaran bawang merah berpotensi menurunkan serangan FOCe. namun belum bisa meningkatkan kommponen pertumbuhan tanaman bawang merah. Perlu dilakukan penelitian lebih lanjut tentang dosis agens hayati yang diberikan agar didapatkan hasil yang lebih akurat.

\section{PERSANTUNAN}

Penelitian ini merupakan bagian dari penelitian unggulan perguruan tinggi UNS 2014 dengan judul Pemaduan Konsorsia Mikrob Fungsional Penyedia Hara dan Agens Hayati Pencegah Penyakit Tular Tanah Sebagai Biofilmed Biofertilizer. Penulis mengucapkan terimakasih atas dukungan dana yang telah diberikan.

\section{DAFTAR PUSTAKA}

Agrios GN. 2005. Plant pathology. 5Ed. San Diego (US): Elsevier Academic Press.

Cramer CS. 2000. Breeding and genetics of fusarium basal rot resistant in onion. J Euphytica 115: 159166. URL: link.springer.com/article/ 10.1023\% 2FA \%3A1004071907642. Accessed 20 September 2014.

Fourie G, Steenkamp ET, Gordon TR, Viljoen A. 2009. Evolutionary relationship amongs Fusarium oxysporum f.sp. cubense vegetative compatibility groups. Appl Environ Microbiol 75(14): 4770. DOI: 10.1128/AEM.00370-09.

Gangadara N, Saifulla B, Nagaraja R. Basavaraja MK. 2010. Biological control of Fusarium oxysporum $\mathrm{f}$. sp. vanillae. The casual agent of stem rot of vanilla in vitro. IJSN 1(2): 259-261. URL: www.scienceandnature.org/IJSN_V1(2)_D2010/IJ SN_V1(2)_30.pdf. Accested 20 September 2014.

Heil M, Bostock RM. 2002. Induced Systemic Resistance (ISR) against pathogens in the context of induced plant defences. Annale Botany 89: 503512. URL: www.bashanfoundation.org/ heil/ heilisr.pdf. Accested 21 September 2014.

Huang $\mathrm{J}$ et al. 2013. The rhizosphere soil of diseased tomato plants as a source for novel microorganisms to control bacterial wilt. Appl Soil Ecol 72: 79-84. DOI: 10.1016/j.apsoil.2013.05.017.

Israel S, Lodha S. 2005. Biological control of Fusarium oxysporum f.sp cumini with Aspergillus vesicolor. Phytopathol. Mediterr 44(1): 3-11. DOI: 10.14601/Phytopathol_Mediterr-1775.

Murali $M$ et al. 2012. Screening for plant growth promoting fungi and their ability for growth promotion and induction of resistance in pearl millet against downy mildew disease. J Phytology 4(5): 30-36. URL: http://journal-phytology.com/ index.php/phyto/article/view/15487/7891. Accested 20 September 2014.

Pal KK, Gardener BM. 2006. Biological control of plant pathogens. Plant Health Instructor. p1-25. DOI: 10.1094/PHI-A-2006-1117-02.

Sastrahidayat IR. 1990. IImu penyakit tumbuhan. Surabaya (ID): Usaha Nasional. 
Shisido $\mathrm{M}$ et al. 2005. Biological control efficiency of fusarium wilt of tomato by nonpathogenic Fusarium oxysporum fo-b2 in different environments. PHYTOPATHOLOGY 95(9): 1072-1080. DOI: 10.1094/ PHYTO-95-1072.

Sintayehu A, Sakhuja PK, Fininsa C, Ahmed S. 2010. Management of fusarium basal rot (Fusarium oxysporum f. sp. cepae) on shallot through fungicidal bulb treatment. Crop Protection 30 (2011): 560-565. DOI: 10.1016/ j.cropro.2010.12.027.

Soesanto L, Rokhlan, Prihatiningsih N. 2009. Penekanan beberapa mikroorganisme antagonis terhadap penyakit layu gladiol. J Agriv 30(1): 7583. URL: jurnal.ub.ac.id/index.php/ agrivita/ article/ view/36. Diakses 23 September 2014.

Song M, Yun HY, Kim HY. 2014. Antagonistic bacillus species as a biological control of ginseng root rot caused by Fusarium cf. Incarnatum. J Ginseng Res 38: 136-145. DOI: 10.1016/j.jgr.2013.11.016

Suárez-Estrella et al. 2013. Biological control of plant pathogens by microorganisms isolated from agroindustrial composts. Biological Control 67: 509515. DOI: 10.1016/j.biocontrol.2013.10.008.
Suprapta DN. 2012. Potential of microbial antagonist as biocontrol agent against plant fungal pathogen. J ISSAAS 18(2): 1-8. URL:www.issaas.org/ journal/ v18/02/journal-issaas-v18n2-01suprapta.pdf. Diakses 28 September 2014.

Susanna. 2006. Pemanfaatan bakteri antagonis sebagai agen biokontrol penyakit layu (Fusarium oxysporum f.sp. cubense) pada tanaman pisang. J Floratek 2: 114-121. URL: jurnal.unsyiah.ac.id/ floratek/article/view/101. Diakses 28 September 2014.

Toyota K, Yamamoto K, Kimura M. 1994. Mechanisms of suppression of Fusarium oxysporum f. sp. raphani in soils so-called suppressive to fusarium-wilt of radish. Soil Sci Plant Nutr 40(3): 373-380. 19. DOI: 10.1080/ 00380768.1994 .10413315$.

Waachjadi M, Loekas S, Abdul M, Endang M. 2013. Pengujian kemampuan mikrob antagonis untuk mengendalikan penyakit hawar daun dan layu bakteri pada tanaman kentang di daerah endemis. Agrin 17(2): 8-20. URL: http://jurnal.faperta. unsoed.ac.id/index.php/jurnal-agrin/article/ download/202/ 186. Diakses 20 September 2014. 